\title{
Pengaruh Senam Aerobik terhadap Profil Hematologi
}

\author{
Sri Hartini Harianja, Ardiya Garini \\ Jurusan Teknologi Laboratorium Medis, Poltekkes Kemenkes Palembang
}

\begin{abstract}
Abstrak
Senam aerobik dengan intensitas ringan hingga sedang akan meningkatkan kesehatan dan kebugaran tubuh. Hal demikian akan memperbaiki dan memperlambat proses penurunan fungsi organ tubuh, serta dapat meningkatkan ketahanan tubuh terhadap serangan infeksi. Tujuan penelitian adalah mengetahui pengaruh intervensi dari senam aerobik terhadap profil hematologi tubuh. Penelitian ini merupakan penelitian praeksperimental one-grup pretest-postest design. Penelitian dilakukan di AKBID Budi Mulya dan Laboratorium Hematologi Jurusan Teknologi Laboratorium Medis, Poltekkes Palembang pada tanggal 02 November 2019. Intervensi yang diberikan berupa senam aerobik intensitas sedang selama 60 menit. Besar sampel penelitian ini adalah 15 orang mahasiswi, rata-rata usia berkisar 19-21 tahun. Pada variabel leukosit $\left(10^{3} / \mathrm{mm}^{3}\right)$ sebelum 6,12 , sesudah 6,74 , Pvalue $0,00<\alpha(0,05)$, variabel hemoglobin $(\mathrm{gr} / \mathrm{dL})$ sebelum 13,07 , sesudah $13,15, \mathrm{P}$-value $0,39>\alpha(0,05)$, variabel eritrosit $\left(10^{6} / \mathrm{mm}^{3}\right)$ sebelum 4,36, sesudah 4,37, P-value $0,83>\alpha(0,05)$, variabel hematokrit $(\%)$ sebelum 37,20, sesudah 37,21, P-value 0,98 $>\alpha(0,05)$, variabel trombosit, $\left(10^{3} / \mathrm{mm}^{3}\right)$ sebelum 319,93 , sesudah $337,67, \mathrm{P}$-value $0,00<\alpha(0,05)$. Pengaruh senam aerobik terhadap profil hematologi memberikan peningkatan nilai pada seluruh profil hematologi. tetapi peningkatan nilai ini tidak memberikan kesan yang melebihi nilai ambang batas normal, ini menunjukkan bahwa dengan senam aerobik mampu merespon sistem seluler dengan baik di dalam tubuh, tanpa memberikan efek stressor bagi tubuh.
\end{abstract}

Kata Kunci : senam aerobik, profil hematologi

\section{Effect of Senam Aerobik on Hematology Profile}

\begin{abstract}
Aerobic exercise with light to moderate intensity will improve your health and fitness. This will increase and slow down the process of organ function decline, and can increase the body's resistance to infection. The aim of this study was to determine the effect of an aerobic exercise intervention on the hematological profile of the body. This study was a pre-test pre-group pre-posttest pre-experimental design. The research was conducted at the Budi Mulya AKBID and the Hematology Laboratory of the Medical Laboratory Technology Department, Palembang Health Polytechnic on November 2, 2019. The intervention provided was in the form of moderateintensity aerobic exercise for 60 minutes. The sample size of this study was 15 female students, the average age ranged from $19-21$ years. On leukocyte variable $\left(10^{3} / \mathrm{mm}^{3}\right)$ before 6.12 , after 6.74 , $\mathrm{P}$ value $0.00<(0.05)$, hemoglobin variable $(\mathrm{gr} / \mathrm{dL})$ before 13.07 , after 13.15 , P-value $0.39>(0.05)$, erythrocyte variable $\left(10^{6} / \mathrm{mm}^{3}\right)$ before 4.36, after 4.37, $\mathrm{P}$ value $0.83>(0.05)$, hematocrit variable $(\%)$ before 37.20 , after $37.21, \mathrm{P}$ value $0.98>$ (0.05), platelet variable, $\left(10^{3} / \mathrm{mm}^{3}\right)$ before 319.93 , after $337.67, \mathrm{P}$ value $0.00<(0.05)$. The effect of aerobic exercise on the haematological profile provides an increase in the value of the entire haematological profile. but the increase in this value does not give the impression that it exceeds the normal threshold value, this indicates that aerobic exercise is able to respond well to cellular systems in the body, without exerting a stressor effect on the body.
\end{abstract}

Keywords: : aerobic exercise, hematological profile

Korespondensi: Sri Hartini Harianja, Jurusan Teknologi Laboratorium Medis, Poltekkes Kemenkes Palembang, Jalan Sukabangun 1 Kelurahan Sukajaya Kecamatan Sukarami Palembang, mobile 081367544320, e-mail srihartiniharianja@poltekkespalembang.ac.id 


\section{Pendahuluan}

Data Riskesdas pada tahun 2018 menunjukkan prevalensi penyakit tidak menular mengalami kenaikan jika dibandingkan dengan Riskesdas 2013, antara lain kanker, stroke, penyakit ginjal kronis, diabetes militus, dan hipertensi (KEMENKES, 2018). Salah satu faktor resiko penyebab penyakit tidak menular adalah kurangnya aktivitas fisik.

Kementerian Kesehatan Republik Indonesia saat ini mencanangkan Gerakan Masyarakat Hidup Sehat (GERMAS), kegiatan ini bertujuan untuk melakukan perubahan pola hidup masyarakat yang semakin modern. Dahulu kasus kesehatan yang banyak ditemui adalah penyakit menular seperti diare, tuberkulosa dan demam berdarah, kini telah terjadi perubahan kasus kesehatan yang banyak ditemui adalah penyakit tidak menular seperti diabetes, kanker dan jantung koroner. Salah satu langkah germas adalah melakukan aktivitas fisik (Indonesia, 2016).

Kemajuan teknologi, membuat sebagian orang malas dalam melakukan aktivitas fisik olah raga seakan bagian yang tidak penting dalam kehidupan, begitu banyaknya alasan untuk tidak sempat melakukan olah raga karena kesibukan, tidak punya waktu luang, dan sulit mengatur waktu. Aktivitas fisik olahraga yang kita lakukan, dikelompokkan menjadi beberapa tingkat yaitu ringan, sedang, dan berat. Latihan aerobik dengan intensitas ringan sampai sedang akan meningkatkan kesehatan dan kebugaran tubuh. Hal demikian akan memperbaiki dan memperlambat proses penurunan fungsi organ tubuh, serta dapat meningkatkan ketahanan tubuh terhadap serangan infeksi. Sedangkan latihan aerobik dengan intensitas maksimal dan melelahkan berdasarkan penelitian dilaporkan terbukti dapat menyebabkan gangguan imunitas. Seorang atlet yang berlatih dengan intensitas latihan yang maksimal dan melelahkan untuk menghadapi suatu pertandingan, sering tidak dapat melanjutkan pertandingan karena sakit atau cedera (Norton et al., 2010; Setyohadi, 2016).

Aktivitas fisik olahraga dapat menimbulkan respon fisiologis pada tubuh, menghasilkan sejumlah perubahan kimia (hormonal), seluler, perubahan fisik seperti peningkatan tekanan darah, suhu tubuh, dan asupan oksigen. Responnya terhadap tubuh tergantung pada jenis aktivitas, intensitas, dan lamanya latihan (Shapoorabadi et al., 2016). Olahraga senam aerobik merupakan aktivitas olahraga yang membutuhkan oksigen dan menggunakan energi dari hasil pembakaran tanpa menimbulkan kelelahan. Olah raga senam aerobik akan memberikan kebugaran fisik berupa kemampuan tubuh untuk berfungsi secara efektif saat bekerja atau melakukan aktivitas lainnya, dan masih memiliki cukup energi tersisa. Senam aerobik dapat membantu melatih otot-otot, melancarkan peredaran darah, mengurangi kejadian penyakit jantung, dan dapat memberi kebahagian dan kesenangan tersendiri. Aktivitas ini bisa kita jadikan gaya hidup sehat di zaman modern saat ini (Pane, 2015; Wen \& Wang, 2017).

Frekuensi olah raga senam aerobik bisa dilakukan secara intensif sebanyak tiga sampai lima kali setiap minggu, intensitas latihan 60$80 \%$ dari denyut jantung maksimal, dan durasi latihan 20 - 60 menit. Penelitian tentang manfaat latihan olahraga terhadap kebugaran fisik telah dilaporkan, dengan latihan olahraga dapat membuang zat-zat sisa metabolisme, sehingga pemulihan berlangsung dengan cepat, dan seseorang tidak akan mengalami kelelahan setelah melaksanakan tugas, serta masih dapat melakukan aktivitas lainnya (Palar et al., 2015; Setyohadi, 2016).

Beberapa penelitian melaporkan bahwa aktivitas fisik berolahraga dapat mempengaruhi parameter hematologi seperti jumlah leukosit (WBC), kadar hemoglobin (HGB), jumlah eritrosit (RBC), nilai hematokrit (HCT), dan jumlah trombosit (PLT). Penelitian dengan memberikan intervensi berupa latihan aerobik ringan dan sedang pada remaja mengambarkan hasil hematologi rutin (WBC, RBC, PLT) masih dalam batas normal dan tidak ada inflamasi yang terjadi. (Setyohadi, 2016) Pada penelitian lainya, sebelum dan sesudah dilakukan intervensi latihan aerobik pada pagi hari dan malam hari memberikan pengaruh peningkatan kadar HGB dan WBC (Isprayoga, 2015). Kita perlu memilih aktifitas fisik yang mampu memberikan kebugaran tubuh bukan malah memberikan efek negatif bagi kesehatan. Tujuan penelitian adalah mengetahui pengaruh intervensi dari senam aerobik terhadap profil hematologi tubuh.

\section{Metode}

Penelitian ini merupakan penelitian praeksperimental dengan pendekatan one-grup pretest-postest design. Penelitian dilakukan di kampus AKBID Budi Mulya Palembang dan Laboratorium Hematologi Jurusan Analis Kesehatan Poltekkes Kemenkes Palembang pada tanggal 02 November 2019. Intervensi 
yang diberikan berupa aktivitas senam pagi selama 60 menit. Besar sampel penelitian ini adalah 15 orang mahasiswi, rata-rata usia berkisar 19-21 . Kriteria inklusi adalah berjenis kelamin perempuan, kondisi sehat, tidak sedang haid, tidak hamil, tidak merokok, bersedia menjadi responden dan telah menandatangani informed consent. Kriteria ekslusi adalah responden dengan riwayat sakit dan mengkonsumsi antibiotik dalam 1 minggu terakhir. Proses pengambilan darah vena dilakukan sebelum dan sesudah setelah aktivitas senam pagi dilakukan. Pengambilan darah vena dilakukan secara aseptik, darah diambil menggunakan alat vacutainer dengan antikoagulan K3 EDTA sebanyak $3 \mathrm{ml}$ untuk masing masing responden. Parameter pemeriksaan yaitu jumlah eritrosit, leukosit, trombosit, dan kadar hematokrit. Pemeriksaan dilakukan dengan menggunakan alat automatic hematology analyzer dengan metode Impendance Flowcytometry. (Pekelharing et al., 2010) Hasil pemeriksaan tiap parameter dianalisis menggunakan uji homogenitas data dengan uji Shapiro-wilk dilanjutkan dengan uji beda rata-rata dua kelompok dependen (paired $t$-test).

Penelitian ini telah mendapatkan persetujuan etik penelitian (ethical clearance) dari Komisi Etik Penelitian Kesehatan Politeknik Kesehatan Makasar No. 964/ KEPKPTKMKS/ VII/ 2019.

\section{Hasil}

Penelitian dilakukan terhadap 15 responden, berjenis kelamin perempuan, berumur rata-rata 20 tahun. Sebelum dilakukan analisis data untuk mengetahui ada tidaknya pengaruh senam pagi terhadap profil hematologi, telah dilakukan uji normalitas data dengan uji Shapiro-wilk. Hasil uji normalitas pada semua data yang diperoleh $\mathrm{P}$ value $>0,05$ ini bermakna semua data terdistribusi normal.

Uji statistik dilanjutkan untuk melihat pengaruh senam pagi terhadap masing masing variabel hematologi dengan menggunakan uji $t$ dependent.

Tabel 1. Karakteristik Responden

\begin{tabular}{lcc}
\hline \multicolumn{1}{c}{ Karakteristik } & $\mathbf{N}$ & $\mathbf{\%}$ \\
\hline Jenis Kelamin & & \\
- Laki-laki & 0 & 0 \\
- Perempuan & 15 & 100 \\
\hline \multicolumn{1}{c}{ Jumlah } & 15 & 100 \\
\hline Umur & & \\
- 19 Tahun & 2 & 13 \\
- 20 Tahun & 10 & 67 \\
- 21 Tahun & 3 & 20 \\
\hline \multicolumn{1}{c}{ Jumah } & 15 & 100 \\
\hline
\end{tabular}

Tabel 2. Pengaruh Senam Aerobik terhadap Profil Hematologi

\begin{tabular}{|c|c|c|c|c|c|c|c|}
\hline \multirow{2}{*}{ Variabel } & \multirow{2}{*}{$\mathbf{n}$} & \multirow{2}{*}{ Umur \pm SD } & \multicolumn{2}{|c|}{ Mean } & \multicolumn{2}{|c|}{ SD } & \multirow{2}{*}{$\begin{array}{c}\text { P- } \\
\text { value }\end{array}$} \\
\hline & & & Sebelum & Sesudah & Sebelum & Sesudah & \\
\hline $\begin{array}{l}\text { Leukosit } \\
\left(10^{3} / \mathrm{mm}^{3}\right)\end{array}$ & 15 & $20,07 \pm 0,59$ & 6,12 & 6,74 & 1,06 & 0,97 & 0,00 \\
\hline $\begin{array}{l}\text { Hemoglobin } \\
\text { ( } \mathrm{gr} / \mathrm{dL})\end{array}$ & & & 13,07 & 13,15 & 0,60 & 0,58 & 0,39 \\
\hline $\begin{array}{l}\text { Eritrosit } \\
\left(10^{6} / \mathrm{mm}^{3}\right)\end{array}$ & & & 4,36 & 4,37 & 0,26 & 0,24 & 0,83 \\
\hline $\begin{array}{l}\text { Hematokrit } \\
(\%)\end{array}$ & & & 37,20 & 37,21 & 1,99 & 1,62 & 0,98 \\
\hline $\begin{array}{l}\text { Trombosit } \\
\left(10^{3} / \mathrm{mm}^{3}\right)\end{array}$ & & & 319,93 & 337,67 & 60,59 & 64,95 & 0,00 \\
\hline
\end{tabular}

Hasil uji statistik dapat dilihat pada Tabel 1, dimana variabel hematologi yang diuji antara lain variabel leukosit, hemoglobin, eritrosit, hematokrit dan trombosit. Pada variabel leukosit terjadi peningkatan, sebelum yaitu 6,12 $\left(10^{3} / \mathrm{mm}^{3}\right) \pm 1,06\left(10^{3} / \mathrm{mm}^{3}\right)$ dan sesudah yaitu $6,74\left(10^{3} / \mathrm{mm}^{3}\right) \pm 0,97\left(10^{3} / \mathrm{mm}^{3}\right)$, hasil analisis menunjukkan adanya perbedaan yang signifikan dengan nilai $\mathrm{P}$-value $0,00<\alpha(0,05)$. Pada variabel hemoglobin terjadi peningkatan, sebelum 13,07 (gr/dL) $\pm 0,60(\mathrm{gr} / \mathrm{dL})$ dan sesudah 13,15 ( gr/dL) $\pm 0,58(\mathrm{gr} / \mathrm{dL})$, tetapi pada hasil analisis menunjukkan tidak ada perbedaan yang signifikan dengan nilai $\mathrm{P}$-value $0,39>\alpha(0,05)$. Pada variabel eritrosit terjadi peningkatan, sebelum $4,36\left(10^{6} / \mathrm{mm}^{3}\right) \pm 0,26$ $\left(10^{6} / \mathrm{mm}^{3}\right)$ dan sesudah $4,37\left(10^{6} / \mathrm{mm}^{3}\right) \pm 0,24$ $\left(10^{6} / \mathrm{mm}^{3}\right)$, tetapi hasil analisis menunjukkan 
tidak adanya perbedaan yang signifikan dengan nilai P-value $0,83>\alpha(0,05)$. Pada variabel hematokrit terjadi peningkatan, sebelum 37,20 $\% \pm 1,99 \%$ dan sesudah $37,21 \% \pm 1,62 \%$, tetapi hasil analisis menunjukkan tidak ada perbedaan yang signifikan dengan nilai P-value $0,98>\alpha(0,05)$. Pada variabel trombosit terjadi peningkatan, sebelum $319,93\left(10^{3} / \mathrm{mm}^{3}\right) \quad \pm$ $60,95\left(10^{3} / \mathrm{mm}^{3}\right)$ dan sesudah $337,67\left(10^{3} / \mathrm{mm}^{3}\right)$ $\pm 64,95\left(10^{3} / \mathrm{mm}^{3}\right)$, hasil analisis menunjukkan ada perbedaan yang signifikan antara kadar trombosit sebelum dan sesudah dengan nilai $\mathrm{P}$ value $0,00<\alpha(0,05)$.

\section{Pembahasan}

Hasil penelitian menunjukkan terjadi peningkatan kadar pada seluruh profil hematologi (leukosit, hemoglobin, eritrosit, hematokrit dan trombosit). tetapi peningkatan nilai ini tidak memberikan kesan yang melebihi nilai ambang batas normal, ini menunjukkan bahwa dengan senam aerobik dengan intensitas sedang mampu merespon sistem seluler dengan baik di dalam tubuh. Sejalan dengan penelitian Atan yang berjudul effek latihan sesaat aerobik dan anaerobik terhadap parameter hematologi, dalam penelitian ini ditemukan adanya peningkatan nilai hematologi satu menit setelah berolahraga. tetapi 60 menit setelah latihan sebagian besar parameter hematologi kembali ke tingkat sebelum latihan (Atan \& Alacam, 2015). Menurut pendapat para ilmuwan bahwa olahraga maupun senam pagi dapat menimbulkan respon fisiologis pada tubuh dan menghasilkan sejumlah perubahan kimia (hormonal) dan seluler, di samping perubahan fisik seperti peningkatan tekanan darah, suhu tubuh, dan asupan oksigen. Ini tergantung pada sejumlah faktor seperti jenis dan lamanya latihan, iklim, status tubuh fisik, dan nutrisi dll (Ashadi, 2014) (Kanca, 2006).

Pengaruh senam aerobik terhadap peningkatan jumlah leukosit, juga dapat disebabkan oleh beberapa faktor, seperti adanya mediasi dari katekolamin, kortisol, demarginasi, neuron transmiters dan peptida atau purine chemical transmiters. Peningkatan jumlah leukosit setelah aktivitas fisik dikarenakan banyaknya leukosit yang mengikuti (masuk) kedalam dinding pembuluh darah (endothelium) dengan cara merembes (diapedesis) ke dalam sirkulasi dari penyimpanannya (cadangan) secara tiba-tiba. Demarginasi dipengaruhi oleh hormon adrenalin yang menyebabkan menurunnya perlekatan leukosit pada endothelium. Hormon, seperti epinefrin dan kortisol, mempengaruhi distribusi WBC dalam sirkulasi darah dan berbagai bagian tubuh, seperti hati, limpa, dan sumsum tulang. Epinefrin meningkatkan jumlah WBC selama latihan (Azarbayjani et al., 2014).

Intensitas dan durasi berolahraga mempengaruhi sistem imun, olah raga yang dilakukan dengan intensitas sedang dan berkala maka akan memberikan respon yang baik terhadap tubuh, berpengaruh terhadap sel-sel imun, seperti: neutrofil, antigen precenting cell $(A P C)$, natural killer cell (NK cell), dan limfosit maupun terhadap produksi sitokin. Olah raga dengan intensitas tinggi menyebabkan kelelahan bisa memberikan pengaruh respon yang tidak baik pada tubuh, bisa berakibat terjadinya inflamasi pada jaringan otot hingga terjadinya leukositosis pada sirkulasi sistemik, kerusakan otot dan organ dalam serta menekan respon imun (Suzuki, 2017; Widiastuti, 2020).

Pengaruh senam aerobik intensitas sedang terhadap peningkatan jumlah eritrosit, hemoglobin dan hematokrit, tetapi tidak signifikan perbedaannya antara sebelum dan sesudah aerobik. Pada olah raga intensitas sedang dapat memberi dampak penggantian eritrosit yang tua menjadi baru dan tidak terjadi fragilitas pada eritrosit seperti yang terjadi akibat latihan berat (Mukarromah, 2010).

Olahraga mempengaruhi sistem pernapasan, sirkulasi, meningkatkan aliran darah melalui paru sehingga menyebabkan oksigen dapat berdifusi ke dalam kapiler paru. Berdasarkan mekanisme transport oksigen ke sel dan jaringan serta mengembalikan $\mathrm{CO} 2$ dari sel dan jaringan ke paru, dapat diketahui bahwa eritrosit dan hemoglobin juga berkontribusi dalam penyediaan oksigen bagi tubuh, sehingga dengan olahraga dapat meningkatkan produksi eritrosit dan memperlancar transport darah yang mengikat oksigen menuju jaringan yang membutuhkan (Konstam et al., 1982; Vieali et al., 2019).

Ketika berolahraga, nilai hematokrit bisa meningkat akibat plasma menurun, dimana ada cairan tubuh yang keluar melalui keringat dan pernafasan yang bisa menyebabkan terjadinya peningkatan trombosit. dehidrasi menyebabkan terjadinya penurunan volume darah yang menyebabkan peningkatan viskositas darah dan menurunkan venous return. Pada kondisi dehidrasi menghasilkan hematokrit yang tinggi palsu, nilai hematokrit akan normal ketika keseimbangan sudah kembali (Astuti, 2019).

Latihan fisik yang berat dan lama juga merupakan stressor bagi tubuh. Tubuh dipaksa melakukan aktivitas lebih dari biasanya. 
Aktivitas yang lebih membutuhkan pasokan oksigen yang lebih pula, terutama aktivitas yang menggunakan sistem energi aerobik. Latihan tidak hanya membutuhkan oksigen yang lebih, namun dapat pula memproduksi radikal bebas dalam tubuh. Selama latihan tubuh akan menghasilkan reactive oxygen species (ROS), yang merupakan radikal bebas. Keadaan ini membuat tubuh akan merespon dengan mempertinggi aktivitas superoxide dismutase (SOD) dan enzim pelindung dalam darah. Selain itu, efek ROS yang tinggi dapat menyebabkan pemecahan hemoglobin yang tinggi. Konsumsi oksigen yang tinggi dan adanya radikal bebas dalam tubuh dapat menyebabkan perubahan kesesuaian hemoglobin selama latihan (Astuti, 2019).

Pengaruh senam aerobik terhadap jumlah trombosit sebelum dan sesudah memberikan peningkatan trombosit yang signifikan, hal ini sejalan dengan penelitian thariq hafiz dengan hasil penelitian menunjukkan terdapat perbedaan yang signifikan sebelum dan setelah aktifitas fisik aerobik terhadap peningkatan jumlah trombosit $(\mathrm{p}=0,000)$. Sejalan dengan penelitian yang dilakukan oleh Azarbayzani bahwa olahraga dapat meningkatkan sementara trombosit secara signifikan dan trombosit segera menurun setelah olahraga. Efek dari aktifitas fisik akut terjadi peningkatan trombosit, hematokrit, kecepatan aliran darah, viskositas plasma, kekakuan eritrosit dan penurunan sedimentasi pada sirkulasi darah setelah aktifitas fisik (Syahputra, 2017). Trombosit diproduksi terkendali dan terstimulasi. Jumlah trombosit akan meningkat selama olahraga, itulah sebabnya peningkatan trombosit yang baru dapat berasal dari pembuluh limpa, sumsum tulang, dan beberapa suplai trombosit lainnya dalam tubuh. Pelepasan epinefrin akan menyebabkan kontraksi limpa yang kuat, di mana hampir sepertiga dari semua trombosit tubuh yang disimpan. Mekanisme ini dapat membenarkan alasan peningkatan kaya trombosit dalam olahraga. Langkah-langkah ekstrim yang dapat mengaktivasi trombosit, dapat disebabkan oleh perubahan pembentukan komponen megakariosit sitoplasma (Azarbayjani et al., 2014).

Kesimpulan yang dapat diambil yaitu pengaruh senam aerobik intensitas sedang sebelum dan sesudah terhadap profil hematologi memberikan peningkatan nilai pada seluruh profil hematologi (leukosit, hemoglobin, eritrosit, hematokrit dan trombosit). tetapi peningkatan nilai ini tidak memberikan kesan yang melebihi nilai ambang batas normal, ini menunjukkan bahwa dengan senam aerobik dengan intensitas sedang mampu merespon sistem seluler dengan baik di dalam tubuh, tanpa memberikan efek stressor bagi tubuh. Senam aerobik sangat baik bagi tubuh kita, maka lakukan secara rutin sebagai kebutuhan tubuh kita.

\section{Ucapan Terima Kasih}

Terima kasih kepada Direktur Poltekkes Kemenkes Palembang atas dana penelitian yang telah diberikan, semoga artikel ini dapat bermanfaat bagi orang banyak.

\section{Daftar Pustaka}

Ashadi, Kunjung. (2014). Implementasi fisiologi olahraga pada olahraga prestasi. Pertemuan ilmiah ilmu keolahragaan nasional Univeritas Negeri Malang. Malang.

Astuti, Rini Wuri. (2019). Hematokrit Dan Kadar Hemoglobin Dengan Konsumsi Oksigen Maksimal (Vo2Maks) Pada Atlet Remaja. Medika Respati: Jurnal Ilmiah Kesehatan, 14(2), 151-161.

Atan, Tulin, \& Alacam, Hasan. (2015). The effects of acute aerobic and anaerobic exercise on blood parameters. The Anthropologist, 19(1), 87-93.

Azarbayjani, Mohammad Ali, Fathi, Rozita, Daloii, Asieh Abbasi, Abdi, Ahmad, \& Fatolahi, Hoseyn. (2014). Acute Hematological Profile Response to One Session of Aerobic and Anaerobic Exercise among Young Male Kickboxers. Turkish Journal of Physical Medicine \& Rehabilitation/Turkiye Fiziksel Tip ve Rehabilitasyon Dergisi, 60(2).

Indonesia, Kemenkes Republik. (2016). Germas Wujudkan Indonesia Sehat.

Isprayoga, Ibnu. (2015). Efektivitas Latihan Aerobik Pagi dan Malam Hari terhadap Kadar Hemoglobin dan Kadar Leukosit (Studi Eksperimen Pada Mahasiswi Ilmu Keolahragaan FIK UNNES). UNIVERSITAS NEGERI SEMARANG. 
Kanca, I Nyoman. (2006). Olahraga dan kesehatan reproduksi. Medikora, 11(2).

KEMENKES, RI. (2018). Potret Sehat Indonesia dari Riskesdas 2018: Badan Penelitian Dan Pengembangan Kesehatan Kementerian RI. http://www ....

Konstam, MA, Tu'Meh, Sabah, Wynne, JOSHUA, Beck, JR, Kozlowski, JOSEPH, \& Holman, BL. (1982). Effect of exercise on erythrocyte count and blood activity concentration after technetium-99m in vivo red blood cell labeling. Circulation, 66(3), 638-642.

Mukarromah, Siti Baitul. (2010). Pengaruh Senam Aerobik Intensitas Sedang Terhadap Kadar Eritrosit dan Hematokrit Darah. Paper presented at the Prosiding Seminar Nasional \& Internasional.

Norton, Kevin, Norton, Lynda, \& Sadgrove, Daryl. (2010). Position statement on physical activity and exercise intensity terminology. Journal of Science and Medicine in Sport, 13(5), 496-502.

Palar, Chrisly M, Wongkar, Djon, \& Ticoalu, Shane HR. (2015). Manfaat latihan olahraga aerobik terhadap kebugaran fisik manusia. eBiomedik, 3(1).

Pane, Bessy Sitorus. (2015). Peranan Olahraga Dalam Meningkatkan Kesehatan. Jurnal Pengabdian Kepada Masyarakat, 21(79), 1-4.

Pekelharing, JM, Hauss, O, De Jonge, R, Lokhoff, J, Sodikromo, J, Spaans, M, . . . Hinzmann, R. (2010). Haematology reference intervals for established and novel parameters in healthy adults. Sysmex Journal International, 20(1), 1-9.

Setyohadi, Dwi. (2016). Perbedaan Kadar Interleukin 4 dan Jumlah Eosinofil setelah Latihan Aerobik Ringan dan Sedang pada Remaja. Berkala Kedokteran, 12(1), 103-116.

Shapoorabadi, Yaser Jafari, Vahdatpour, Babak, Salesi, Mansour, \& Ramezanian, Hadiseh. (2016). Effects of aerobic exercise on hematologic indices of women with rheumatoid arthritis: A randomized clinical trial. Journal of research in medical sciences: the official journal of Isfahan University of Medical Sciences, 21.

Suzuki, K. (2017). Exhaustive exercise-induced neutrophil-associated tissue damage and possibility of its prevention. J. Nanomed. Biother. Discov, 7, 156.

Syahputra, Thariq Hafiz. (2017). Pengaruh Aktifitas Fisik Aerobik dan Anaerobik terhadap Jumlah Trombosit pada Mahasiswa Ilmu Keolahragaan 2015 Universitas Negeri Medan. UNIMED.

Vieali, Afrizal Ilfian, Kinanti, Rias Gesang, \& Andiana, Olivia. (2019). Survei kadar eritrosit pada atlet sepakbola Aji Santoso Indonesia Football Academy (ASIFA) Kota Malang. Jurnal Sport Science, 9(2), 105-110.

Wen, Hongwei, \& Wang, Lijuan. (2017). Reducing effect of aerobic exercise on blood pressure of essential hypertensive patients: A meta-analysis. Medicine, 96(11).

Widiastuti, Ida Ayu Eka. (2020). Immune Response to Sports. Jurnal Kedokteran, 9(2), 166-174. 